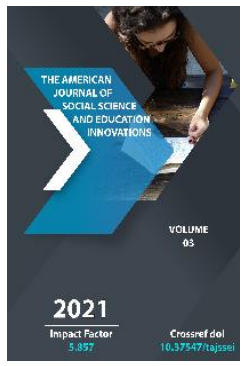

\title{
The Name Of Our Country Will Be Praised By The Followers Of Kamoliddin Bekhzod
}

\section{Nodirbek Sayfullaev}

Assistance Professor, Candidate Of Historical Sciences, Rector Of The National Institute Of Art And Design Which Is Named After Kamoliddin Behzod, Uzbekistan

\section{ABSTRACT}

\section{On the way to higher education}

In recent years, under the leadership of the President Shavkat Miromonovich Mirziyoyev, great changes have taken place in the higher education system, as well as in all areas. Consequently, the confidence of our people in this field is strengthening, and the desire of youngsters for higher education is growing from year to year.

The Presidential Decree "On approval of the Concept of development of the higher education system of the Republic of Uzbekistan until 2030" states important tasks such as "raising the content of higher education to a qualitatively new level, the establishment of a system of training highly qualified personnel who can make a worthy contribution to the sustainable development of the social sphere and the economy, find their place in the labor market".

\section{KEYWORDS}

Higher education system, development, President, Uzbekistan

"In today's world, where the glorious power of our people has stirred, it is true to say that a new awakening is being laid in Uzbekistan - the foundation of the Third Renaissance. Because today's Uzbekistan is not yesterday's Uzbekistan. Our people today are not the people of yesterday. "

\section{Sh.M.Mirziyoev,}

President of the Republic of Uzbekistan 


\section{INTRODUCTION}

\section{A new period in fine and applied arts}

Obviously, in recent years, as a result of the attention and care paid by the President to the development of art and culture, many innovations and achievements in the field of fine and applied arts and design, many achievements and updates are being highlighted. It is no exaggeration to say that the Presidential Decree "On measures to further increase the efficiency of the fine and applied arts", published on 21 April, this year, has opened a new historical period in the field. On the basis of the decision, we express our respect to the great historical person, the founder of Uzbek miniature art Kamoliddin Behzod. We do this through the producing of a documentary film, the creation of a new statue of the artist, the holding of international scientific conferences, and a number of other tasks which are pointed in the document. Secondly, through this, we inform our people, especially the young generation, about Kamoliddin Behzod, his creative heritage, and the history of our country in general. This, in turn, plays an important role in bringing up our youth in the spirit of high patriotism.

To add to it, in accordance with the decision, starting from the 2020/2021 academic year, a state scholarship named after Kamoliddin Behzod will be established for students who are studying in the field of fine and applied arts and design. Gradually, this stimulates the creative aspirations of students, their efforts to create innovations and serves as a basis for their development into mature professionals in the future.
A center for retraining and advanced training of teachers and specialists in the field of art education and an experimental workshop for artists (higher art course) were established and their tasks were defined. As a result, the value of highly qualified specialists in the field of art education and the quality of education will increase.

In the vicinity of the main building of the National Institute of Art and Design, named after Kamoliddin Behzod, it is planned to build an additional educational building and a modern information and library center, an ancillary building, which includes an exhibition gallery. As a consequency, the quality and efficiency of training will be improved by strengthening the material and technical base of the institute.

Shortly, the resolution covers a wide range of issues like fully conveying the rich creative heritage of Kamoliddin Behzod to our people, retraining and advanced training of personnel in the field, as well as the development of art education, and we need to ensure its consistent implementation.

\section{Wide range of opportunities for creative students}

Ensuring the practical implementation of 5 important initiatives put forward by the President has become one of the main activities of the institute. Professors, teachers and students of the institute are organizing regularly master classes and exhibitions in order to awake affection for fine and applied arts on the younger generation and explaining them the secrets of this field deeply. During the quarantine period, works in this area continued 
online and was broadcasted on the Internet and on television regularly.

Due to the nature of the institute, to support and encourage young talented students, to demonstrate their talents, to awake in young people a sense of involvement in the ongoing reforms in our country such as "Five Initiatives - Five Opportunities", "Strong Family - the backbone of the country" and "The most active art critic" contests were organized. Due to quarantine, the deadline for online submission of creative works to these competitions has been extended again. It is also planned to organize these competitions in the traditional way every year, turning the award ceremony into another art festival for young people.

Furtherly to support and encourage the creativity of students during the quarantine period, an online contest "Stay home and create" was organized. For this competition, a separate channel was opened on the telegram messenger, and the creative works which were submitted by the students were posted regularly. More than 600 creative works were accepted for this competition, and the winners were determined by open voting. The winners and prize-winners of the contest were awarded with diplomas and souvenirs at the online cultural-educational event "Youth Initiative" on the occasion of June 30 - Youth Day. Madina Norchaeva, Aigul Tojiddinova, Behzod Juraboev, Nodira Mirjonova, Bakhtiyor Dedashev, Tursunmurad Musurmonov, Rano Yahshilikova, Dilfuza Nematova, Sarvinoz Tugalova, Bunyod Zoirjonov, Hilola Yuldasheva who are the winners of many national and international awards, Laureates of the Zulfiya State Prize, who set an example for their peers with their talent and effective creative activity, are studying in our institute. In order to ensure future creators with creative works of the staff in the spirit of the great reforms taking place in our country, students are given creative assignments based on today's requirements. In order to ensure that future creative staff create in the spirit of the great reforms taking place in our country, students are given creative assignments based on today's requirements. As a result, they are having a deeper understanding of the changes taking place in our country, and their works and creations are able to convey the essence of these changes to the general public.

\section{International cooperation connections}

As new Uzbekistan is facing the world, its art and culture are also developing in tandem with the world. The institute also has established cooperation with a number of prestigious foreign universities, with which about 40 memorandums have been signed. In the international cooperation, 70 of our professors and 16 students took part in advanced training, internships, seminars and conferences. 2 professors and 22 students took part in the exchange programs. The MUSAE project was received under the Erasmus + program.

Also, in cooperation with Kemyon University of the Republic of Korea in the field of Design (clothing and fabrics) on the basis of joint educational programs, in cooperation with the Channapatana Design Institute in Thailand on the basis of joint educational programs in the field of Design (interior design) and Design (clothing and fabrics) have set in motion. In the 2019/2020 academic year, Yale University in the United States, Change School in the United Kingdom, and the University of Birmingham City organized master classes, scientific seminars, and workshops for future artists, art historians, and fashion designers. 
Delegation exchanges were held to expand cooperation with a number of institutions, including the Shanghai Academy of Arts and Design of the National Republic of China, the University of Birmingham City in the United Kingdom, the Institute of Architecture and Art of the National Academy of Sciences of Azerbaijan.

\section{Scientific potential is a solid foundation}

In art education, as in any field, scientific analysis and finding solutions to the problems of the field is important for future development. With this in mind, the institute pays great attention to the development of scientific research, as well as creative innovations.

While quarantine measures are underway in our country, international scientific online conferences on "Universal values and traditions in art" and "Problems of national identity in art in the context of globalization" have been held. Experts from the Russian Federation, Germany, Great Britain, Switzerland, the People's Republic of China, Malaysia, Bulgaria, Lithuania, the Republic of Belarus, Armenia, the Republic of Moldova, Kazakhstan, Thailand and other countries took part in the event with their lectures and expressed their views on the history of art, today and tomorrow. At the same time, these conferences provided an opportunity for young researchers of our country to study international experience and gain a deeper understanding of the current processes in world art.

\section{The combination of theory and practice}

Unless the learning process is directly linked to production practices, there will be problems in training qualified personnel. With this in mind, at the beginning of this year, branches of the Department of Museum Studies were established at the State Museum of Art of Uzbekistan and the State Museum of History of Uzbekistan.

Within the framework of the cooperation, the State Museum of Arts of Uzbekistan will hold such workshops as "Excursion Studies", "Museum Interior Design", "Fundamentals of Museum Work", "Photography" and practical training in museum expositions and reserves, and in the State Museum of History of Uzbekistan such subjects as "Examination and restoration of museum objects" are being taught. The institute is working on a number of other projects in this area.

The concept of development of the higher education system of the Republic of Uzbekistan until 2030 sets priorities for the systemic reform of higher education in the Republic of Uzbekistan. A number of tasks have been set, such as the development of the social sphere and the economy, based on advanced educational technologies. Ensuring their implementation has become one of the important tasks on the agenda of the institute. As the only higher education institution in Uzbekistan specializing in art education, we aim to make the institute an important center for the further development of the industry.

\section{Responsibility for admission processes}

One of the urgent tasks of today is to train highly qualified, competitive specialists who meet the requirements of the times, have a broad outlook and independent thinking. One of the most important steps in accomplishing this task is undoubtedly the acceptance process. 
It is known that on August 3, 2017, at a meeting with creative intellectuals, the President abolished tests in higher education institutions specializing in the training of creative personnel, and introduced the practice of admitting prospective students only through creative exams.

This is not only a high level of confidence, but also a huge responsibility. After all, in this process, the future of the applicant, who applied for the institute, will largely depend on the assessment of him by the staff of the field.

In turn, the staff of the National Institute of Art and Design named after Kamoliddin Behzod, deeply aware of the trust and responsibility entrusted to them, and combining the positive experience gained over the past two years, are working to organize the admission process fairly and transparently. In particular, all examination processes are recorded in our higher education institution with the help of video surveillance cameras and displayed online on the official website of the institute, on social media pages. Academicians of the Academy of Arts of Uzbekistan, national artists of Uzbekistan, artists of Uzbekistan, doctors of sciences and professors, who do not work at the institute, are involved in the evaluation of the work of entrants. The results of the exam will be announced on the same day on the website of the institute.

Given the pandemic situation, in order to conduct this year's exams in a simplified form, it is planned for applicants to take a professional (creative) exam in only one subject. In other words, in all creative directions will be submitted for 160 minutes in the direction of "Composition", and in the direction of art criticism on the subject of "History of Fine and Applied Arts". Also, exams in such areas as Museum Studies and Management: (art management and gallery work) were transferred to a full test form.

Most importantly, the institute, in cooperation with relevant ministries and agencies, is taking all necessary measures to prevent corruption, acquaintanceship and other abominations in the admission process. Realizing that the young people recommended for students today will determine the future of the industry, all employees of the institute are taking this process seriously.

This year's professional (creative) exam programs have been revised taking into account the pandemic conditions, approved by the relevant order of the Academy of Arts of Uzbekistan on June 24, 2020 and in the database of legislation on June 30, 2020 10/20/3261/1084 registered with.

For the first time, in the admission of the 2020/2021 academic year, the official website of the institute published a database of assignments for each direction in the professional (creative) exams two months before the start of the test exams. This allowed applicants to prepare for these exams at home during the quarantine conditions.

This year's professional (creative) exams are scheduled to be held daily by region for an average of 200-250 entrants, and these entrance exams will last from September 3 to September 15, 2020.

Also, during the professional (creative) exams, special attention is paid, first of all, to the health of applicants and the rules of quarantine. While last year's professional (creative) exams prepared a place for 20-22 entrants per audience, this year a place has 
been prepared for 8-9 entrants, keeping the social distance to these auditoriums.

These auditoriums are specially designed for artists, artists repairing works of applied art, designers, potters, sculptors, computer graphics and art photographers, depending on the nature of the field of study.

All entrants in the same conditions are provided by the institute with the necessary equipment such as medical masks and gloves, water and paper, canvas, clay for professional (creative) exams to perform tasks in their specialty.

In turn, we can see that the interest of young people in the fields of fine and applied arts, design, art history, museum studies is growing from year to year. In the 2019/2020 academic year, the number of applicants wishing to study at the institute was 1,526 , while for the $2020 / 2021$ academic year it was 2,489. The number of entrants this year increased by 963 people or $38 \%$ compared to last year.

These figures alone testify to the effectiveness of reforms in the sector.

In order to ensure the practical implementation of the Resolution of the President of the Republic of Uzbekistan "On measures to further increase the effectiveness of fine and applied arts" and the further development of art education in our country, the staff of the institute has set a number of tasks. The institute also pays special attention to improving art education, development of scientific and creative processes in accordance with modern requirements, improving the quality and effective organization of art education, as well as strengthening its material and technical base.
In short, the National Institute of Art and Design named after Kamoliddin Behzod aims to nurture talented people who can make a worthy contribution to the development of art and culture of our country, who are wellrounded, worthy followers of Kamoliddin Behzod and other great artists. As Mir Alisher Navoi, the sultan of the property of poetry, said, "Not educating a talented person is cruelty and educating a disabled person is dangerous."

\section{REFERENCES}

1. Resolution of the President of the Republic of Uzbekistan dated April 21, 2020 No PR4688 "On measures to further increase the efficiency of the fine and applied arts." // "Khalk suzi", April 22, 2020, №82 (7584).

2. Decree of the President of the Republic of Uzbekistan No. PD-6000 of May 22, 2020 "On measures to further enhance the role and influence of culture and art in society." // " Khalk suzi ", May 28, 2020, №112 (7614).

3. Speech by the President of the Republic of Uzbekistan Sh. Mirziyoyev at the solemn ceremony dedicated to the twenty-ninth anniversary of the independence of the Republic of Uzbekistan // "Yangi Uzbekistan", September 1, 2020, № 167 (167)

4. Гузеев В. Образовательная технология XXI века: деятельность, ценности, успех. Москва: «Педагогический поиск», 2004.

5. N.Sayfullaev. Current issues on fne arts education: continuity and prospects for development.// RELIGACIÓN. Revista de Ciencias Sociales y Humanidades. - Web of Science. 2019. - Vol.4. - №19

6. Абдурашидовна, қ. Д. (2020). АЭВИД ФОНДИ ВА КОЛЛЕКЦИЯЛАРИДАГИ ЎЗБЕКИСТОННИНГ $Х$ АСРИГА ОИД АШЁЛАР ВА УЛАРНИНГ ЎЗИГА ХОС 
ХУСУСИЯТЛАРИ. Маданият чоррахалари, 4(2).

7. Kurbanova, D. A. (2016). ANCIENT PEARLS IN GREAT WORLD MUSEUMS WHICH BELONG TO THE HISTORY OF UZBEKISTAN AND LEARNING THEM. Социосфера, (3), 55-61.

8. Kurbanova, D. (2020). Tent Of The Emir Of Bukhara (Second Half Of The 19th Century)(History Of One Exhibit From The Collection of The State Hermitage). The American Journal of Social Science and Education Innovations, 2(12), 180-183. 